\title{
Identifying and evaluating E-procurement in supply chain risk by Fuzzy MADM
}

\author{
Mohammad Mahdi mozaffari $^{\mathbf{a}^{*}}$, Hassan Khodaei Valehzagharad ${ }^{\mathrm{a}}$, Reza Kiani Mavi ${ }^{\mathrm{b}}$ and Mostafa \\ Memarzade $^{\mathbf{a}}$
}

${ }^{a}$ Department of Industrial Management, Imam Khomeini International University (IKIU), Qazvin, Iran

${ }^{b}$ Department of industrial Management, Islamic Azad University(IAU), Qazvin Branch, Qazvin, Iran

\begin{tabular}{l}
\hline A R T I C L E I N F O \\
\hline Article history: \\
Received October 15, 2011 \\
Received in Revised form \\
October, 30, 2011 \\
Accepted 30 January 2012 \\
Available online \\
9 February 2012 \\
\hline Keywords: \\
E-procurement \\
Risk management \\
Fuzzy logic \\
MADM
\end{tabular}

$$
\text { A B S T R A C T }
$$

E-procurement risks has emerged as an important issue for researchers and practitioners because mitigating supply chain risk helps improve firms' as well as supply chains' performance. E-marketplaces have been steadily growing and there have been significant interest in e-business research. There are different risks and uncertainties involved with Emarketplaces, which jeopardizes the sector but we have had a large amount of hype and the business still continue to grow. The primary aim of this study is to identify E-procurement risks and evaluate them using a fuzzy AHP framework. We contribute E-procurement risk by identifying 13 critical criteria and determine four important ones including the extent of acceptable information, interrelationship risk, lack of honesty in relationships and product quality and safety for evaluating suppliers’ risk.

\section{Introduction}

Over the past 10 years, earthquakes, economic crises, SARS, strikes, terrorist attacks have disrupted supply chain operations repeatedly. Supply chain (SC) disruptions can have significant impact on a firm's short-term performance. There are many negative effects of having possible disruption on supply chain and it could eventually reduce the performance of a firm. For instance, Hendricks and Singhal (2005) report that companies suffering from supply chain disruptions experienced 33-40\% lower stock returns relative to their industry benchmarks. With the logic integration of numerous managerial risk factors in SC risk system, there is a need to have comprehensive risk assessment models to improve stability of decision-making process and pertinence of risk measurements selected.

We present an analysis path for the framework based on the operational process cycle (OPC) and the product life cycle (PLC), as well as SC organizational performance factors (OPF) and available risk operational practice (ROP). 
Risk management is considered as the main contributor to different fields of management decision and control (Giannakis et al., 2004). The characteristics of the contribution of risk management in the supply chain management field was assessed by Brindley (2004) who reported that global competition, technological change for competitive advantage are among some of the most important issues behind organizations turning towards risk management approaches.

There are many advantages associated with outsourcing activities but there have been corresponding increases in the level of existing uncertain events with suppliers. These risk components tend to increase when disparate services are provided by the different trading partners (Sims \& Standing, 2002). The increase use of internet and intranet systems has shorten many time consuming tasks involved with business units (Heim and Sinha, 2005; Ranaweera et al., 2008).

E-marketplaces have grown rapidly in recent years and have received remarkable attention in ebusiness infrastructures (Palmer et al., 2000). The change in the nature of the marketplace along with increases and varieties of customer demands, advances of information technologies and communication, competition in global environment, decreases in governmental regulations and increases in environmental consciousness have led companies to focus on supply chain management (Tracey \& Tan, 2001).

In order to form the E-supply chain and its effective coordination to have customer satisfaction and sustainable competency, we need to have a complex of information, materials, and funds across multiple functional regions in companies. Therefore, we need to identify, evaluate, rank, and manage its supply chain risks. According to Tang (2006), for mitigating supply chain disruptions and highlighted the strategies we cannot only rely on robust strategies to manage the inherent fluctuations efficiently by ignoring the occurrence of major disruptions. The primary outcome of ignoring major risks will lead to a more resilient supply chain in the face of major disruptions.

It is normally a good idea to have an increasing number of choices for risk management techniques and tools in practice (Huchzermeier, 2000). However, we have to handle them with their different functionalities and features, which is often a tedious task. In this paper, we respond to this challenge by proposing a decision-making model and a methodology for SC risk management. The primary goal of this study is to identify and evaluate e-procurement risks. Identifying and evaluate Eprocurement risks is a multi-criteria problem, which includes both qualitative and quantitative factors. Therefore, we need to have a tradeoff between these tangible and intangible items, where some of them may be in serious conflict (Ghodsypour \& O’Brien, 1998).

The first step in this study is to extract E-procurement risks and it is important to choose a scientific and rational evaluation. We also need an appropriate method for evaluating the weights of each item. Since we are dealt with a multi criteria decision making approach we need to detect the appropriate technique. The fuzzy set theory approaches are able to incorporate human reasoning in use of approximate information and uncertainty to generate decisions. Furthermore, fuzzy logic has been integrated with MADM to deal with vagueness and imprecision of human thought. For the determination of the relative importance of selection risks, fuzzy AHP can be used since it is based on pairwise comparisons and allows the utilization of linguistic variables.

The organization of this paper is as follows. Section 2 discusses the literature review. In Section 3, we explain the process of the research, fuzzy AHP and SIGRA method. Section 4 briefly describes the case study. Section 5 is data analysis and the paper ends with concluding remarks in section 6 . 


\section{Literature review}

\subsection{Risks management}

Risk management processes is associated with different stages a supply chain or a company could follow to reduce the supply chain risks. Supply disruption risk is described as managers' perception of the total potential loss created from disruptions on the supply from suppliers to buyers (Ellis et al., 2010). It consists different activities such as identifying supply chain risk events, assessing the probabilities and the severity of impacts, prioritizing the risk event to be dealt with and developing actions for mitigating risks or planning for backup actions.

Tang (2006) classifies four techniques to mitigate the impact of such supply chain risks:

1- Demand management: coordination with downstream partners to impact demand in a beneficial manner;

2- Product management: change in services or process design to make more fluent the material flows in the supply chain;

3- Information management: collaboration among supply chain dealers by sharing information; and

4- Supply management: cooperation with upstream partners to make sure of supply of materials.

Dickson (1989) defined risk management as "The identification, analysis and control of those risks which can threaten the assets or earning capacity of an enterprise”. Risk management must continue through the process, which runs in the organization's strategy and the implication of the strategy. It needs to consider all the existing risks surrounding the organization's activities past, present and in particular, future (Khan \& Burnes, 2007).

Actual process of risk management starts by evaluating two factors: firstly, the likelihood of specific events occurring; and the consequences should the events actually occur (Cox \& Townsend, 1998). According to The Royal Society (1992), the risk management process is defined as making and implementing decisions concerning risks based on risk estimation and risk assessment.

\subsection{E-procurement risks}

The history of risk assessment goes back to seventeenth century (Frosdick, 1997) and research on risk was first investigated to the business context in the 1950's (Snider, 1991). The ideas of risk and risk management were studied in detail by different people in various fields such as economics, finance and strategy (Tversky \& Kahneman, 1992; Ting, 1988; Manuj \& Mentzer, 2008).

Risk can be described as a chance of damage, loss, danger, injury or any other undesired consequences. According to the Royal Society (1992) risk is defined as "the probability that a particular adverse event occurs during a stated period of time, or results from a particular challenge”. According to Spekman and Davis (2004), in context of business management, risk is also defined as "the probability of variation in potential results in both objective and subjective ways".

According to Mitchell (1995) risk in supply chains is an important issues since companies, which are unable to manage it are likely to suffer in terms of performance. Poorly managed risks can lead to inaccurate prediction, low quality products, low turnover and share price, loss of reputation, and poor relationships with the other members of the supply chain and conflict amongst the organization's stakeholders (Cousins et al., 2004). Companies need to consider supply chain risk management strategies to eliminate, or at least mitigate these effects (Christopher, 2005; Manuj \& Mentzer, 2008). 
There are different types of supply chain risks. Chopra and Sodhi (2004) grouped supply chain risks into disruptions, delays, systems, forecast, intellectual property, procurement, receivables, inventory, and capacity. Cucchiella and Gastaldi (2006) categorized supply chain risks in two different groups of internal involving different internal activities such as capacity variations, regulations, information delays, and organizational factors.

They also consider many external activities such as market prices, actions of competitors, manufacturing yield and costs, supplier quality, and political issues. According to Juttner, Peck and christofer (2003) Supply Chain risks can be categorized in two various aspects of risk and uncertainty sources and risk consequences, which mean risk impacts on business.

Johnson (2001) claimed that there are two groups of supply chain risk: Demand risk, which consists of seasonality, volatility, new product adoption and short product life cycle, and supply risk, which happens by disruptions in supply, production capacity and logistics as well as long lead-time between supply and demand. Kleindorfer and Saad (2005) explained that different risks arising from coordinating complex systems of supply and demand (internal), and disruptions (external).

Wang (2005) investigated the sources of supply chain default risk and the influence on supply chain value created by default risk using tools of Game theory, and presented some techniques for identifying risks from the perspective of partner selection. Ma and Fu (2007) combined fuzzy sets with influence diagram theory and considered the interaction among risk factors. The new market and commercial opportunities handled by the Internet facilitate the change and complexity in supply networks, and consequently increase risk.

There has also been some technological transformation in purchasing using e-business technologies, which help organizations with a wide range of benefits such as savings in transaction costs, inventory reduction, and the establishment of communication networks between buyers and suppliers (DeeterSchmelz et al. 2001).

The level of perceived risk that a customer associates with a buying decision is higher in online shopping than in traditional shopping (Cunningham et al., 2005; Samadi \& Yaghoob-Nejadi, 2009; Taylor, 1993). Risk involves the uncertainty regarding the outcome of a decision and the costs that this decision might imply for the buyer, as other authors have done for the online context (Gefen et al., 2002).

Technological risks are the outcome of integration, incompatible applications and security issues related with the volatile internet environment. Technological risks influence suppliers to adopt different technological applications provided by the buyers known as technology squeeze. As Croom (2000) claimed supply networks become complex and dynamic as a result of combined, messy, intertwined effects of increasing product/service complexity, outsourcing globalization and ebusiness.

The risk in e-procurement is important because only those firms with low risk-avoidance profiles prefer e-procurement (Juan, 1999) and this is a common fact that the higher the lever of risk, the lower the possibility of transaction success (Taylor, 1993).

The risks associated with e-marketplace are extracted from poor business practices arising from applying weak standards, which lead to technology implementation problems (Vaidyanathan \& Devaraj, 2003). We summarized some of E-procurement risks highlighted by researchers in eprocurement. Table 1 demonstrates details of the criteria. 
Table 1

List of criteria and definition

\begin{tabular}{|c|c|}
\hline Criteria & Definition \\
\hline $\begin{array}{lcc}\text { C1: The extent of } \\
\text { acceptable information }\end{array}$ & Our reliability of correctness of information that is reached from commercial partner \\
\hline C2: interrelationship Risk & partner; the vulnerability that's caused by process \\
\hline $\begin{array}{l}\text { C3: The sudden cancellation } \\
\text { of orders }\end{array}$ & Cancel order suddenly from commercial partners \\
\hline $\begin{array}{l}\text { C4: Lack of honesty in } \\
\text { relationships }\end{array}$ & $\begin{array}{l}\text { Trust may concern a partner's willingness to perform according to agreement, or the } \\
\text { intention to do so. Risks exist if the party is not competent to act or if the party chooses } \\
\text { not to act }\end{array}$ \\
\hline C5: Appropriate e-market & $\begin{array}{l}\text { An electronic marketplace is an "inter-organizational system that allows participating } \\
\text { buyers and sellers to exchange information about processes, products, and services }\end{array}$ \\
\hline C6: Operating & $\begin{array}{l}\text { Affects a firm's internal ability to produce and supply goods/servi } \\
\text { consequences of a breakdown in a core operating, manufacturing or }\end{array}$ \\
\hline $\begin{array}{lll}\text { C7: } & \text { External } & \text { and } \\
\text { uncontrollable events }\end{array}$ & The events that are happened out of company and are uncontrollable \\
\hline C8: Strategic uncertainty & ementation \\
\hline C9: Supplier Opportunism & $\begin{array}{l}\text { Opportunism refers to a lack of honesty in transactions and is manifest in such acts as } \\
\text { withholding or distorting information with the intent to mislead, and failing to fulfill } \\
\text { promises or obligations }\end{array}$ \\
\hline $\begin{array}{l}\text { C10:Product quality and } \\
\text { safety }\end{array}$ & $\begin{array}{l}\text { Defective, damaged, or wrong product, components or materials; differences across } \\
\text { multiple sites }\end{array}$ \\
\hline C11: The technology & $\begin{array}{l}\text { Technological risks are the result of integration issues, incompatible applications and } \\
\text { security issues associated with the volatile internet environment. Technological risks } \\
\text { impact suppliers forcing them to adopt different technological solutions provided by the } \\
\text { buyer }\end{array}$ \\
\hline $\begin{array}{l}\text { C12: commitment and } \\
\text { capability }\end{array}$ & $\begin{array}{l}\text { The commitment that commercial partners have because of the company plan and their } \\
\text { ability and capability of doing works. }\end{array}$ \\
\hline C13: Competitive & n’s ability to differentiate its products/services from its competitors \\
\hline
\end{tabular}

\section{Methodology}

This study proposes fuzzy AHP method to engage the challenge of risks evaluation. Our experts are ten people of different companies in various industries with over 10 years of experience in their jobs. Four people of our expert team are from technical management departments and six people of our expert team are from business management departments. First, we define risks criteria extracted from e- procurement risks literature. In this risk evaluation problem, the relative importance of different decision criteria involves a high degree of subjective judgment and individual preferences. The linguistic assessment of human feelings and judgments are vague and it is not reasonable to represent them in terms of precise numbers. It feels more confident to give interval judgments. Therefore, triangular fuzzy numbers were used in this problem to decide the priority of one decision criteria over another. The triangular fuzzy numbers were determined from reviewing literature (Kahraman, C.; Cebeci, U.; Ulukan, Z., 2003). In order to evaluate the weights of risks obtained by e- procurement risks literature, fuzzy AHP was used.

\subsection{Fuzzy Analytic Hierarchy Process}

Laarhoven and Pedrycz (1983) introduced the Fuzzy Analytic Hierarchy Process (FAHP), which is a combination of Analytic Hierarchy Process (AHP) and Fuzzy Theory. The linguistic scale of AHP method expresses the fuzzy uncertainty when a decision maker is making a decision. Therefore, FAHP converts the opinions of experts from previous definite values to fuzzy numbers and membership functions, presents triangular fuzzy numbers in paired comparison of matrices to develop FAHP, thus the opinions of experts approach human thinking model, so as to achieve more 
reasonable evaluation criteria. Table 3 shows details of our fuzzy numbers along with their linguistic definitions.

\section{Table 3}

Linguistic variables for weight of each criterion

\begin{tabular}{lllllllll}
\hline $\begin{array}{l}\text { Extremely } \\
\text { strong }\end{array}$ & Intermediate & $\begin{array}{l}\text { Very } \\
\text { strong }\end{array}$ & Intermediate & Strong & Intermediate & $\begin{array}{l}\text { Moderately } \\
\text { strong }\end{array}$ & $\begin{array}{l}\text { Intermediate } \\
\text { Equally } \\
\text { strong }\end{array}$ \\
\hline$(9,9,9)$ & $(7,8,9)$ & $(6,7,8)$ & $(5,6,7)$ & $(4,5,6)$ & $(3,4,5)$ & $(2,3,4)$ & $(1,2,3)$ & $(1,1,1)$ \\
\hline
\end{tabular}

The steps of this study based on FAHP method are as follows:

1) Determine problems: Determine the current decision problems to be solved, so as to ensure future analyses correct; this study discussed the "evaluation criteria for verification of supplier selection criteria”.

2) Set up hierarchy architecture: Determine the evaluation criteria having indexes to be the criteria layer of FAHP, for the selection of evaluation criteria, relevant criteria and feasible schemes can be found out through reading literatures. This study screened the important factors conforming to target problems through FDM investigating experts' opinions, to set up the hierarchy architecture.

3) Construct pairwise comparison matrices among all the elements/criteria in the dimensions of the hierarchy system. Assign linguistic terms to the pairwise comparisons by asking which is the more important of each two dimensions, as following matrix $\tilde{A}$ :

$$
\tilde{A}=\left(\begin{array}{cccc}
1 & \tilde{a}_{21} & \cdots & \tilde{a}_{21} \\
\tilde{a}_{21} & 1 & \cdots & \tilde{a}_{21} \\
\tilde{a}_{21} & \tilde{a}_{21} & \cdots & 1
\end{array}\right)=\left(\begin{array}{cccc}
1 & \tilde{a}_{21} & \cdots & \tilde{a}_{21} \\
\frac{1}{\tilde{a}_{21}} & 1 & \cdots & \tilde{a}_{21} \\
\frac{1}{\tilde{a}_{21}} & \frac{1}{\tilde{a}_{21}} & \cdots & 1
\end{array}\right)
$$

where $\tilde{a}_{i j}= \begin{cases}\tilde{9}^{-1}, \tilde{8}^{-1}, \tilde{7}^{-1}, \tilde{6}^{-1}, \tilde{5}^{-1}, \tilde{4}^{-1}, \tilde{3}^{-1}, \tilde{2}^{-1}, \tilde{1}^{-1}, \tilde{1}, \tilde{2}, \tilde{3}, \tilde{4}, \tilde{5}, \tilde{6}, \tilde{7}, \tilde{8}, \tilde{9} \quad i \neq j \\ 1 & i=j\end{cases}$

4) To use geometric mean technique to define the fuzzy geometric mean and fuzzy weights of each criterion by Hsieh et al. (2004).

$\tilde{r}_{i}=\left(\tilde{a}_{i 1} \otimes \tilde{a}_{i 2} \otimes \ldots \otimes \tilde{a}_{i n}\right), \tilde{w}_{i}=\tilde{r}_{i} \otimes\left(\tilde{r}_{1} \oplus \tilde{r}_{2} \oplus \ldots . \oplus \tilde{r}_{n}\right)^{-1}$

Where $a_{i j}$ is fuzzy comparison value of dimension $i$ to criterion $j$, thus, $\tilde{r}_{i}$ is a geometric mean of fuzzy comparison value of criterion $i$ to each criterion, $\tilde{w}_{i}$ is the fuzzy weight of the ith criterion, can be indicated by a TFN, $\tilde{w}_{i}=\left(l w_{i}, m w_{i}, u w_{i}\right)$. The $l w_{i}, m w_{i}$ and $u w_{i}$ stand for the lower, middle, and upper values of the fuzzy weight of the ith dimension.

\subsection{Evaluating e-procurement risks by Fuzzy AHP}

We adopt FAHP method to evaluate the weights of different criteria for E-supply chain risks. Following the construction of fuzzy AHP model, it is extremely important that experts fill the judgment matrix. According to the committee with ten representatives about the relative important of risks, the pairwise comparison matrices of criteria will be obtained. We apply the fuzzy numbers defined in Table 4. We transfer the linguistic scales to the corresponding fuzzy numbers. All necessary computation of the elements of synthetic pairwise comparison matrix are performed using the geometric mean method suggested by Buckley (1985). 
It can be obtained the other matrix elements by the same computational procedure, therefore, the synthetic pairwise comparison matrices of the five representatives will be constructed as follows matrix A:

Table 7

Fuzzy comparison matrix for the relative importance of criteria

\begin{tabular}{|c|c|c|c|c|c|c|c|c|c|c|c|c|c|}
\hline & C1 & C2 & C3 & C4 & C5 & C6 & C7 & C8 & C9 & C10 & C11 & C12 & C13 \\
\hline & 1.000 & 0.896 & 1.534 & 1.149 & 1.414 & 1.888 & 2.595 & 1.534 & 3.016 & 1.072 & 3.757 & 4.891 & 3.464 \\
\hline \multirow[t]{2}{*}{ C1 } & 1.000 & 1.218 & 1.829 & 1.568 & 1.891 & 2.514 & 3.410 & 2.015 & 3.846 & 1.494 & 4.393 & 5.551 & 4.592 \\
\hline & 1.000 & 1.534 & 2.130 & 2.024 & 2.349 & 3.116 & 4.265 & 2.604 & 4.680 & 1.990 & 5.016 & 6.175 & 5.627 \\
\hline \multirow{3}{*}{ C2 } & 0.652 & 1.000 & 1.282 & 1.103 & 1.259 & 1.741 & 2.635 & 0.836 & 1.866 & 0.642 & 2.325 & 3.232 & 2.259 \\
\hline & 0.821 & 1.000 & 1.676 & 1.568 & 1.608 & 2.451 & 3.123 & 1.108 & 2.515 & 0.788 & 3.105 & 4.051 & 2.788 \\
\hline & 1.116 & 1.000 & 2.169 & 2.107 & 1.973 & 3.157 & 565 & 1.490 & 3.194 & 0.990 & 3.887 & & 3.232 \\
\hline \multirow{3}{*}{ C3 } & 0.470 & 0.461 & 1.000 & 0.552 & 0.922 & 0.880 & 1.578 & 0.836 & 1.866 & 0.642 & 2.325 & 3.232 & 2.259 \\
\hline & 0.547 & 0.597 & 1.000 & 0.749 & 1.162 & 1.116 & 2.221 & 1.108 & 2.515 & 0.788 & 3.105 & .051 & 2.788 \\
\hline & 0.652 & 0.780 & 1.000 & 1.072 & 1.473 & 1.453 & 2.814 & 1.490 & 3.194 & 0.990 & 3.887 & 4.810 & 3.232 \\
\hline \multirow{3}{*}{ C4 } & 0.494 & .475 & 0.933 & 1.000 & 1.000 & .405 & 1.911 & 1.282 & 1.488 & 0.728 & 3.194 & 3.565 & 2.625 \\
\hline & 0.638 & 638 & 1.335 & 1.000 & 1.231 & 1.863 & 2.431 & 1.762 & 2.056 & 0.943 & 3.989 & 4.624 & 3.837 \\
\hline & 0.871 & 0.907 & 1.813 & 1.000 & 1.463 & 2.294 & 2.942 & 2.268 & 2.744 & 1.311 & 4.925 & 5.694 & 4.951 \\
\hline \multirow{3}{*}{ C5 } & 0.426 & .507 & 0.679 & 0.683 & 1.000 & 0.933 & 1.644 & 1.182 & 2.144 & 0.664 & 2.862 & 3.424 & 2.094 \\
\hline & 0.529 & 622 & 0.922 & 812 & 1.000 & 1.133 & 2.021 & 1.706 & 2.786 & 0.851 & 3.719 & 4.518 & 2.631 \\
\hline & 0.707 & 0.794 & 1.210 & 1.000 & 1.000 & 1.414 & 2.352 & 2.232 & 3.464 & 1.096 & 4.494 & 5.533 & 3.152 \\
\hline \multirow{3}{*}{ C6 } & 0.321 & 0.317 & 0.688 & 0.436 & 0.707 & 1.000 & 1.282 & 0.933 & 1.710 & 0.524 & 2.130 & 3.228 & 1.835 \\
\hline & 0.398 & & & 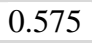 & 0.882 & 1.000 & 1.810 & 41 & 2.295 & 0.717 & 2.608 & 4.028 & 2.373 \\
\hline & 0.530 & .574 & 1.137 & 0.794 & 1.072 & 1.000 & 2.392 & 1.550 & 2.941 & 0.988 & 3.189 & 4.803 & 2.896 \\
\hline \multirow{3}{*}{ C7 } & 0.234 & 0.280 & 0.397 & 0.340 & 0.425 & 0.418 & 1.000 & 0.568 & 1.149 & 0.367 & 1.516 & 1.943 & 1.149 \\
\hline & 0.293 & 0.320 & 0.483 & 0.411 & 0.495 & 0.552 & 1.000 & 0.732 & 1.395 & 0.449 & 1.918 & 2.601 & 1.486 \\
\hline & 0.385 & 0 & & 3 & 0.608 & 0.780 & 0 & 0.896 & 1.681 & 0.562 & 2.325 & 3.288 & 1.943 \\
\hline \multirow{3}{*}{ C8 } & 0.384 & 0.420 & 0.671 & $0.0^{2}$ & 0.448 & 0.645 & 1.1 & 1.000 & 1.692 & 0.696 & 1.835 & 2.491 & 2.000 \\
\hline & 0.496 & 0.515 & 0.903 & 0.568 & 0.586 & 0.806 & 1.366 & 1.000 & 2.214 & 0.815 & 2.498 & 3.325 & 2.479 \\
\hline & & & & & 0.846 & 1.072 & & & 2.748 & 0.950 & 3.232 & 215 & 2.930 \\
\hline \multirow{3}{*}{ C9 } & 0.214 & 0.259 & 0.313 & 3 & 0.289 & 0.340 & 0.595 & 0.364 & 1.000 & 0.332 & 1.231 & 625 & 0.758 \\
\hline & 0.260 & 313 & 0.398 & 0.486 & 0.359 & 0.436 & 17 & 0.452 & 1.000 & 0.367 & 1.681 & 181 & 0.975 \\
\hline & 0.332 & 0.385 & 0.536 & 0.672 & 0.467 & 0.585 & 0.871 & 0.591 & 1.000 & 0.419 & 2.107 & 2.670 & 1.282 \\
\hline \multirow{3}{*}{ C10 } & 0.503 & 0.608 & 1.011 & 0.763 & 0.876 & 0.876 & 1.780 & 1.141 & 2.389 & 1.000 & 2.806 & 4.089 & 2.862 \\
\hline & 0.669 & 7 & & & & .141 & & .370 & 2.726 & 1.000 & 3.432 & 5.140 & 3.712 \\
\hline & 0.933 & 0.846 & 1.557 & 1.374 & 1.374 & 1.473 & 726 & 1.669 & 3.016 & 1.000 & 4.089 & 6.103 & 4.517 \\
\hline \multirow{3}{*}{ C11 } & 0.199 & 0.199 & 0.257 & 0.205 & 0.223 & 0.314 & 0.430 & 0.309 & 0.475 & 0.245 & 1.000 & 1.217 & 0.707 \\
\hline & 0.228 & 0.233 & 0.322 & 0.251 & 0.269 & 0.383 & & 0.400 & 0.595 & 0.291 & 1.000 & 1.604 & 0.903 \\
\hline & 0.266 & & & & 0.349 & .470 & 0.660 & .545 & 0.812 & 0.356 & 1.000 & 2.107 & 1.162 \\
\hline \multirow{3}{*}{ C12 } & 0.162 & & & & 0.181 & 0.208 & 0.304 & 0.228 & 0.374 & 0.164 & 0.475 & 1.000 & 0.430 \\
\hline & 0.180 & 0.200 & 0.247 & 0.216 & 0.221 & 0.248 & 0.384 & 0.284 & 0.459 & 0.195 & 0.624 & 1.000 & 0.549 \\
\hline & 0.204 & 0.238 & 0.309 & 0.280 & 0.292 & 0.310 & 15 & 0.370 & 0.616 & 0.245 & 0.822 & 1.000 & 0.736 \\
\hline \multirow{3}{*}{ C13 } & & & & 2 & 0.0 & & 515 & 41 & 0.780 & 0.221 & 0.860 & 358 & 1.000 \\
\hline & 0.218 & 0. & & 0 & 0.380 & 0.421 & & 0.403 & 1.025 & 0.269 & 1.107 & 1.823 & 1.000 \\
\hline & 0.289 & 0.315 & 0.443 & 0.381 & 0.478 & 0.545 & 0.871 & 0.500 & 1.320 & 0.349 & 1.414 & 2.325 & 1.000 \\
\hline
\end{tabular}

To calculate the fuzzy weights of criteria, the computational procedures are displayed as following parts:

$\tilde{r}_{1}=\left(\tilde{a}_{11} \otimes \tilde{a}_{12} \otimes . \tilde{a}_{13} \otimes \tilde{a}_{14} \otimes \tilde{a}_{15} \otimes \tilde{a}_{16} \otimes \tilde{a}_{17} \otimes \tilde{a}_{18} \otimes \tilde{a}_{19} \otimes \tilde{a}_{110} \otimes \tilde{a}_{111} \otimes \tilde{a}_{112} \otimes \tilde{a}_{113}\right)^{\frac{1}{13}}$. Therefore, we have,

$$
\begin{array}{llll}
\tilde{r}_{1}=(1.871,2.368,2.864) & \tilde{r}_{2}=(1.717,2.143,2.595) & \tilde{r}_{3}=(1.076,1.359,1.692) & \tilde{r}_{13}=(0.409,0.5,0.633) \\
\tilde{r}_{4}=(1.278,1.661,2.105) & \tilde{r}_{5}=(1.137,1.426,1.755) & \tilde{r}_{6}=(0.909,1.159,1.463)
\end{array}
$$


$\tilde{r}_{7}=(0.599,0.732,0.909) \quad \tilde{r}_{8}=(0.871,1.092,1.385) \quad \tilde{r}_{9}=(0.478,0.59,0.739)$

$\tilde{r}_{10}=(1.309,1.625,1.983) \quad \tilde{r}_{11}=(0.364,0.44,0.55) \quad \tilde{r}_{12}=(0.266,0.319,0.4)$

For the weight of each criterion, they can be done as follows:

$\tilde{w}_{i}=\tilde{r}_{i} \otimes\left(\tilde{r}_{1} \oplus \tilde{r}_{2} \oplus . \tilde{r}_{3} \oplus \tilde{r}_{4} \oplus \tilde{r}_{5} \oplus \tilde{r}_{6} \oplus \tilde{r}_{7} \oplus \tilde{r}_{8} \oplus \tilde{r}_{9} \oplus \tilde{r}_{10} \oplus \tilde{r}_{11} \oplus \tilde{r}_{12} \oplus \tilde{r}_{13}\right)^{-1}$

Table 8 shows details of our results.

Table 8

The weights and rank of criteria

\begin{tabular}{llllllllllllll}
\hline$\tilde{W}_{j}$ & $\tilde{W}_{1}$ & $\tilde{W}_{2}$ & $\tilde{W}_{3}$ & $\tilde{W}_{4}$ & $\tilde{W}_{5}$ & $\tilde{W}_{6}$ & $\tilde{W}_{7}$ & $\tilde{W}_{8}$ & $\tilde{W}_{9}$ & $\tilde{W}_{10}$ & $\tilde{W}_{11}$ & $\tilde{W}_{12}$ & $\tilde{W}_{13}$ \\
\hline $\mathrm{a}$ & 0.098 & 0.090 & 0.056 & 0.067 & 0.060 & 0.048 & 0.031 & 0.046 & 0.025 & 0.069 & 0.019 & 0.014 & 0.021 \\
$\mathrm{~b}$ & 0.154 & 0.139 & 0.088 & 0.108 & 0.093 & 0.075 & 0.047 & 0.071 & 0.038 & 0.105 & 0.029 & 0.021 & 0.032 \\
$\mathrm{c}$ & 0.233 & 0.211 & 0.138 & 0.171 & 0.143 & 0.119 & 0.074 & 0.113 & 0.060 & 0.161 & 0.045 & 0.033 & 0.052 \\
\hline
\end{tabular}

\section{Conclusion}

The aim of this research was to construct a simple and reliable model to evaluate the e-procurement risks for industries. We have used Fuzzy AHP method in this study because of reliability of this method. We have a comprehensive study on supply chain and E-procurement risks and 13 indicators were extracted by this study and ranked them using FAHP ranking technique. The proposed model of this paper used fuzzy logic to handle the uncertainty associated with different criteria.

The findings show that, the extent of acceptable information, interrelationship risk, lack of honesty in relationships and product quality and safety are the most important indicators for evaluating risks in E-procurement.

\section{References}

Agrell, P. J., Lindroth, R., \& Norrman, A. ((2004). Risk, information and incentives in telecom supply chains. International Journal of Production Economics, 1-16.

Alvandi, M., Elahi, M., Memarzade, M., \& Hesaraki, A. (in press). Developing a new MADM method (SIGRA) by integrating SIR and GRA methods. American journal of scientific research.

Arnold, D., \& Quelch, J. (1998). New strategies in emerging markets. Sloan Management Review, 720.

Baird, I., \& Thomas, H. (1990). What is Risk Anyway?” In R.A. bettis and H,Thomas(EDs),risk strategy, and management. Greenwich,CT: JAI press.

Barry, J. (2004). Perspectives: supply chain risk in an uncertain global supply chain environment. International Journal of Physical Distrubtion and Logistics Management, 34(9), 397-695.

Bellman, R., \& Zadeh, L. (1970). Decision-making in a fuzzy environment management. Science, 17, 141-164.

Berry, A. J., \& Collier, P. M. (2007). Risk in supply chains: exploratory case studies in the automotive industry. International Journal of Risk Assessment and Management, 1005-1026.

Bevilacqua, M., Ciarapica, F., \& Giacchetta, G. (2006). A fuzzy-QFD approach to supplier selection. Journal of Purchasing and Supply Management, 14-27.

Bidhandi, H., Yusuff, R., Ahmad, M., \& Abu Bakar, M. (2009). Development of a new approach for deterministic supply chain network design. European Journal of Operational Research, 198, 121128. 
Blackhurst, J., Craighead, C., Elkins, D., \& Handfield, R. (2005). an empirically derived agenda of critical research issues for managing supply-chain disruption. International Journal of Production Research, 4067-4081.

Brindley, C. (2004). Supply Chain Risk, Ashgate, Aldershot.

Buckley, J.-J. (1985). Fuzzy hierarchical analysis. Fuzzy Sets and Systems, 17, 233-247.

Cevikcan, C., Sebi, S., \& Kaya, I. (2009). Fuzzy VIKOR and fuzzy axiomatic design versus to fuzzy TOPSIS: An application of candidate assessment. Journal of Multiple Valued Logic and Soft Computing, 15, 181-208.

Chan, F., \& Kumar, N. (2007). Global supplier development considering risk factors using fuzzy extended AHP-based approach. Omega, 35, 417-431.

Chen, H., Chen, J., \& Chen, Y. (2006). A coordination mechanism for a supply chain with demand information updating. International Journal of Production Economics, 347-361.

Chen, Y.-J., \& Seshadri, S. (2006). Supply chain structure and demand risk. Automatica, 1291-1299.

Choi, T. Y., \& Krause, D. R. (2006). The supply base and Its complexity:implications for transaction costs,risk,responsiveness, and innovation. Journal of Operation Management, 637-652.

Chopra, S., \& Sodhi, M.S. (2004). Managing risk to avoid supply-chain breakdown. MIT Sloan Management Review, 46(1), 53-62.

Choy, K. L., Li, C.-L., So, S. C., Lau, H., Kwok, S. K., \& Leung, D. W. (2007). Managing uncertainty uncertainty in logistics service supply chain. International Journal of Risk Assessment and Management, 19-43.

Christopher, M. (2005). Logistics and Supply Chain Management: Creating Value-Adding Networks. $3^{\text {rd }}$ ed., FT Prentice-Hall, Harlow.

Christopher, M., \& Lee, H. (2004). Mitigating supply chain risk through improved confidence. Internationl Journal of physical Distribution and logistics management, 388-396.

Christopher, M., \& Peck, H. (2004). Building the resilient supply chain. International Journal of Logistics Management, 15, 1.

Chu, M.-T., Shyu, J., Tzeng, G.-H., \& Khosla, R. (2007). Comparison among three analytical methods for knowledge communities group-decision analysis. Expert Systems with Applications, 33, 1011-1024.

Cousins, P., Lamming, R.C., \& Bowen, F. (2004). The role of risk in environment-related initiatives. International Journal of Operations \& Production Management, 24(6), 554-565.

Cox, A., \& Townsend, M. (1998). Strategic Procurement in Construction. Thomas Telford, London.

Croom, S.R. (2000). The impact of Web-based procurement on the management of operating resources supply. Journal of Supply Chain Management, 36 (1), 4-13.

Cucchiella, F., \& Gastaldi, M. (2006). Risk management in supply chain: a real option approach. Journal of Manufacturing Technology Management, 17(6), 700-20.

Dobbs, H. (1998). Competition's New Battleground. Cambridge: The Integrated Value Chain.

Dowling, G., \& Staelin, R. (1994). A model of perceived risk and intended risk-handling activity. Journal of Consumer Research, 21, 119-134.

Dyer, J. (2000). Collaborative Advantage. Oxford.: Oxford University Press.

Eisenhardt, K. (1989). Agnecy theory:an assessment and review. Academy of Management Review, 57-74.

Ellis, S. C., Henry, R.M., \& Shockley, J. (2010). Buyer perceptions of supply disruption risk: A behavioral view and empirical assessment. Journal of Operations Management, 28(1), 34-46.

Faisal, M., Banwet, D., \& Shankar, R. (2007). Supply chain risk management inSMEs: Analysing the barriers. International Journal of Management and Enterprise Development.

Finch, P. (2004). Supply chain risk management. Supply Chain Management: An International Journal, 183 - 196.

Frohlich, M., \& Westbrook, R. (2001). Arcs of integration: an international study of supply chain strategies. Journal of Operations Management, 19, 185-200. 
Frosdick, S. (1997). The techniques of risk analysis are insufficient in themselves. Disaster Prevention and Management, 6(3), 165-177.

Gaudenzi, B., \& Borghesi, A. (2006). Managing risks in the supply chain using the AHP method. International Journal of Logistics Management, 114-139.

Gefen, D., Rao, V.S., \& Tractinsky, N. (2002). The conceptualization of trust, risk and their relationship in electronic commerce. The need for clarifications. Proceedings of $36^{\text {th }}$ Hawaii International Conference on System Sciences (HICSS ’03), Hawaii, 92-201.

Ghodyspour, S.H., \& O’Brien, C. (1998). A decision support system for supplier selection using an integrated analytic hierarchy process and linear programming. International Journal of Production Economics, 56-57, 199-212.

Giaglis, G. M., Minis, I., Tatarakis, A., \& Zeimpekis, V. (2004). Minimizing logistics risk through real-time vehicle routing and mobile technologies: Research to date and future trends. International Journal of Physical Distribution \& Logistics Management.

Giannakis, M., Croom, S., \& Slack, N. (2004). Supply chain paradigms, in New, S. and Westbrook, $R$. (Eds), Understanding Supply Chains, Oxford University Press, Oxford, 1-22.

Giménez, C., \& Lourenço, H. (2004). E-supply chain management: Review, implications and directions for future research. Barcelona: Universitat Pompeu Fabra.

Giunipero, L. C., \& Eltantawy, R. A. (2004). Securing the upstream supply chain: a risk management approach. international Journal of Physical Distribution \& Logistics Management, 698 - 713.

Guillen, G., Mele, F. D., Bagajewicz, M. J., Espuna, A., \& Puigjaner, L. (2005). Multiobjective supply chain design under uncertainty. Chemical Engineering Science, 1535-1553.

Gulledge, T., \& Mason, G. (2000). B2B e-marketplaces and small- and medium-sized Enterprise. Manufacturing Information Systems, Proceedings of the Forth SME International Conference, 17.

Hallikas, J. K., Pulkkinen, U. V.-M., \& Tuominen, M. (2004). Risk management processes in supplier networks. International Journal of Production Economics, 90, 47-58.

Hallikas, J., Virolainen, V.-M., \& Tuominen, M. (2002). Risk analysis and assessment in network environments: A dyadic case study. International Journal of Production Economics, 45-55.

Handfield, R. (1993). the role of materials managenet in developing time-based competition. International Journal of Purchasing and Materials Management, 2-10.

Harland, C., Brenchley, R., \& Walker, H. (2003). Risk in supply network. Journal of Purchasing and Supply Management, (1), 51-62.

Harland, C., Knight, L., \& Sutton, R. (2001). Information for supply interventions: sector network and organization opportunities from network and organization opportunities from e-commerce. 10th International Annual Conference ofInternational Purchasing and Supply Education and Research Association, Sweden.

Kahraman, C., Cebeci, U., \& Ruan, D. (2004). Multi-attribute comparison of catering service companies using fuzzy AHP: The case of Turkey. International Journal of Production Economics, 87, 171-184.

Khan, O., \& Burnes, B. (2007). Risk and supply chain management: creating a research agenda. International Journal of Logistics Management, 18(2), 197-216.

Kleindorfer, P.R., \& Saad, G.H. (2005). Managing disruption risks in supply chains. Production and Operations Management, 14(1), 53-68.

Klir, G., \& Yuan, B. (1995). Fuzzy sets and fuzzy logic - Theory and application. New Jersey: Prentice-Hall Inc.

Laarhoven, P., \& Pedrycz, W. (1983). A fuzzy extension of Sati’s priority theory. Fuzzy Sets and System, 11, 229-241.

Koh, S., Demirbag, M., Bayraktar, E., Tatoglu, E., \& Zaim, S. (2007). The impact of supply chain management practices on performance of SMEs. Industrial Management \& Data Systems, 107, 103-124.

Kralijic, P. (1983). purchasing must become supply management. Harvard Business Review, 109117. 
Krause, D., \& Handfield, R. (1999). Developing a world-class supply base. Center for Advanced Purchasing Studies.

Le, T. (2002). Pathways to leadership for business-to-business electronic marketplaces. Electronic Markets, 12(2), 112-9.

Lee, H.L., \& Whang, S. (2001). E-Fulfillment: Winning the Last Mile of E-Commerce. MIT Sloan Management Review, 42(4),54-62.

Lee, H., Padmanabhan, V., \& Whang, S. (1997). Information distortion in a supply chain:The Bullwhip Effect. Management Science, 43(4), 546-558.

Ma, H., Ma, Q., \& Fu, G. (2007). Evaluation of Supply Chain Default Risk Based on Fuzzy Infulence Diagram. Journal of Southeast University (English Edition), 23, 111-117.

Malone, T., Yates, J., \& Benjamin, R. (1987). Electronic markets and electronic hierarchies. Communications of the ACM, 30, 484-497.

Norrman, A., \& Jansson, U. (2004). Ericsson's proactive supply chain risk management approach after a serious sub-supplier accident. International Journal of Physical Distribution and Logistics Management, 34(5), 434-456.

Ojala, M., \& Hallikas, J. (2006). Investment decision-making in supplier networks: Management of risk. International Journal of Production Economics, 104(1), 201-213.

Opricovic, S. (1998). Multi-criteria optimization of civil engineering systems. Belgrade: Faculty of Civil Engineering.

Opricovic, S., \& Tzeng, G.-H. (2002). Multicriteria planning of post-earthquake sustainable reconstruction. Computer-Aided Civil and Infrastructure Engineering, 17, 211-220.

Opricovic, S., \& Tzeng, G.-H. (2004). Compromise solution by MCDM methods: A comparative analysis of VIKOR and TOPSIS. European Journal of Operational Research, 156(2), 445-455.

Palmer, J.W., Bailey, J.P., \& Faraj, S. (2000), The role of intermediaries in the development of trust on the www: the use and prominence of trusted third parties and privacy statements. Journal of Computer Mediated Communication, 5(3).

Pathak, J. (2004). A conceptual risk framework for internal auditing in e-commerce. Managerial Auditing Journal, 19(4), 556-564.

Pathak, J., \& Baldwin, A. (2003). Generation-X technology and auditors: a paradigm shift. Proceedings of 12th Annual Research Workshop of Artificial Intelligence/Emerging Technology. Honolulu, HI.: 2 August, American Accounting Association,.

Peck, H. (2005). Drivers of supply chain vulnerability:an integrated framework. International Journal of Physical Distribution and Logistics Management, 35(4), 210-232.

Premkumar, G. (2003). Perspectives of the e-marketplace by multiple stakeholders. Communications of the ACM, 46(12), 279-88.

Qi, X., Bard, J. F., \& Yu, G. (2004). Supply chain coordination with demand disruptions. The International Journal of Management Science, 34(2), 301-312.

Ranaweera, C., Bansal, H., \& McDougall, G. (2008). Web site satisfaction and purchase intentions: impact of personality characteristics during initial web visit. Managing Service Quality, 18(4), 329-48.

Rao, S., \& Goldsby, T. J. ( 2009). Supply chain risks: a review and typology. The International Journal of Logistics Management, 20(1), 97-123.

Towill, D. R. (2005). The impact of business policy on bullwhip induced risk in supply chain management. International Journal of Physical Distribution and Logistics Management, 35(8), 555-575.

Tracey, M. \& Tan, C.L. (2001). Empirical analysis of supplier selection and involvement, customer satisfaction, and firm performance. Supply Chain Management: An International Journal, 6(4), 174-188.

Tversky, A., \& Kahneman, D. (1992). Advances in prospect theory: cumulative representation of uncertainty. Journal of Risk and Uncertainty, 5(4), 297-323. 
Vaidyanathan, G., \& Devaraj, S. (2003). A five-factor framework for analyzing onlinerisks in ebusinesses. Communications of the ACM, 46(12), 354-61.

Wang, Y. (2005). The Study of Default Risk in Supply Chain. Ph.D. dissertation, Hohai University.

Wagner, S. M., \& Bode, C. (2006). An empirical investigation into supply chain vulnerabilit. Journal of Purchasing and Supply Management, 12(6), 301-312.

Walker, G., \& Weber, D. (1984). A transaction cost approach to make or buy decision. Administrative Science Quarterly.

Walton, S., Handfield, R., \& Melnyk. (1998). the Green supply chain:integrating suppliers into environmental management processes. International Journal of Purchasing and Materials Management, 2-11.

Watson, G. (2004). Uncertainty and contractual hazard in the film industry: managing adversarial collaboration with dominant suppliers. Supply Chain Management, 9(5), 402-409.

Wilson, M. C. (2007). The impact of transportation disruptions on supply chain performance. Transportation Research Part E: Logistics and Transportation Review, 43(4), 295-320.

Wilson, T. (2000). Integration: key to surviva. Retrieved from Internet Week: www.internetweek.com/lead/lead102300.htm

Wise, R., \& Morrison, S. (2000). "Beyond the exchange - the future of B2B. Harvard Business Review, November/December, 86-96.

Wu, T., Blackhurst, J., \& Chidambaram, V. (2006). A model for inbound supply risk analysis. Computers in Industry, 57(4), 350-365.

Wynstra, F., Van Weele, A., \& Weggemann, M. (2001). management supplier involvement in product developement:three critical issues. European management journal, 19(2), 157-67.

Yates, J.F., \& Stone, E. (1992). The Risk Construct, in Yates, J.F. (Ed.), Risk-taking Behaviour, Wiley, Chichester.

Zadeh, L. A. (1965). Fuzzy sets. Information and Control, 8, 338-353. 